\title{
Violence exposure and substance use among southern Brazilian schoolchildren
}

\author{
Cristina Lessa Horta ${ }^{1,2}$, Carolina Saraiva de Macedo Lisboa ${ }^{1}$, Vanessa Andina Teixeira ${ }^{2}$, \\ Guilherme Welter Wendt ${ }^{3}$, Rogério Lessa Horta² \\ ${ }^{1}$ Pontifical Catholic University of the Rio Grande do Sul \\ ${ }^{2}$ Unisinos University \\ ${ }^{3}$ Goldsmiths, University of London
}

(Received March 10, 2015; Accepted June 22, 2015)

\begin{abstract}
Cross-sectional study with probabilistic sample of 3,547 adolescents aged from 12 to 17 years old, $54.2 \%$ girls, from southern Brazilian schools that analysed the association between exposure to violence and substance use. Gender and age distribution in general population were controlled and sample proportions were assured. A self report measure was used to evaluate sociodemographic conditions, violence, substance use, psychiatric disorders, school performance, parental practices and relationship with parents and teachers. Descriptive analysis were hold, prevalence ratio for substance use were estimated by Poisson Regression, preceded by control for design effect by school variable. The analysis were adjusted by gender, alcohol and tobacco use by the parents and psychiatric disorders. Association between violence exposure and use in the year of all drugs investigated was found: tobacco $[P R=2.49$ (CI95\%: 1.92-3.25) $p<.001]$, alcohol [PR=1.46 (CI95\%: 1.35-1.59) $p<.001]$ and illicit drugs $[P R=1.60(C 195 \%: 1.27-2.01) p<.001]$. When adjusting also for the use of other substances (for example: cocaine, crack), the association remained only for tobacco and alcohol. Prevalence substance use found are similar to national levels and there are evidences of significant and strong association of substance use and exposure to violence at school, mainly for alcohol and tobacco. It is recommended that public policies to improve school climate and school context should focus on school staff skills and competencies to prevent school violence and licit or illicit substance use by Brazilian adolescents.
\end{abstract}

Keywords: drugs, school health, adolescence.

\section{Exposición a la violencia y el consumo de sustancias entre estudiantes en el sur de Brasil}

RESUMEN: Este estudio transversal con muestra probabilística de 3.547 adolescentes, $54.2 \%$ niñas, media de edad 14 años $(S D=1.66)$, realizado en escuelas brasileñas del sur de Brasil, analizó la asociación entre la exposición a la violencia y el consumo de sustancias. El género y la edad fueron controlados y la proporción de la muestra fue asegurada. Una medida de autoinforme ha evaluado datos sociodemográficos, la violencia, el consumo de sustancias, trastornos psiquiátricos, rendimiento escolar, prácticas parentales y la relación de los jóvenes 
con padres y profesores. Se realizó análisis descriptivo y la razón de prevalencia para el consumo de sustancias fue estimada por regresión de Poisson, precedida por el control para efecto de la variable escuela. El análisis fue ajustada por sexo y el consumo de alcohol y tabaco por los padres, así como por los trastornos psiquiátricos. Asociaciones entre la exposición a la violencia y el uso en el año de todos las sustancias investigadas fueron encontradas: tabaco $[P R=2.49$ (IC 95\%: 1.92 - 3.25) $p<.001]$, alcohol $[P R=1.46$ (IC95\%: 1.35-1.59) $p<.001]$ y drogas ilícitas $[P R=1.60$ (IC95\%: $1.27-2.1) p<.001]$. Al ajustar para el uso de cualquier sustancia de otros grupos, la asociación sólo quedó para el consumo de tabaco y de alcohol. La prevalencia del consumo de sustancias encontrada fue similar a los niveles nacionales. Se recomienda que las políticas públicas para mejorar el clima de las escuelas brasileñas se centren en las competencias del equipo escolar para prevenir la violencia y el consumo de sustancias por adolescentes.

Palabras clave: drogas, salud escolar, adolescencia.

\section{INTRODUCTION}

Violence and use of psychoactive substances are public health problems significantly affecting adolescents not only in Brazil but also in the world (Brasil, 2010; Luk, Wang, \& Simons-Morton, 2012; Radliff, Wheaton, Robinson, \& Morris, 2012). Each year, more than one million people lose their lives as a consequence of violent acts, being this one of the leading causes of death between the ages of 15 and 44 years-old around the world (Dahlberg \& Krug, 2006). In Brazil, violence situations along with involvement in accidents constitute the third cause of death in the general population and the first among those who are up to 39 years-old, evidencing that Brazilian teenagers are often victimized by violent acts (Dahlberg \& Krug, 2006) and, in many cases, also are the perpetrators of these acts (World Health Organization [WHO], 1996). It is also important to address that as problems that affect adolescents, the use of drugs and violence are evidenced in schools contexts. Related to a negative school climate, the drug abuse and violence in schools represent important risk factors to the learning process itself and adolescents' well-being (Luk, Wang \& Simons-Morton, 2012; Malta et al., 2011; Radliff, Wheaton, Robinson, \& Morris, 2012).

Different studies point to the fact that the involvement in violence situations could compromise the physical, social, cognitive and psychological development of all individuals involved - victims, perpetrators or witnesses (Madruga et al., 2011; Ok \& Aslan, 2010). These effects extend not only through childhood and adolescence, but also through adulthood (Madruga et al., 2011). Among the possible damages caused by this phenomenon are: problems on self-esteem, difficulties in peer relations, difficulties in learning, truancy, use of alcohol, tobacco and illicit drugs, violent behaviors, conduct disorder, psychosomatic symptoms, risky sexual behavior, depression and suicide (Collins Fantasia, Sutherland, \& Kelly-Weeder, 2012; Cruzeiro et al., 2008; Radliff et al., 2012; Tortorelli, Carrei- 
ro, \& Araújo, 2010).

International data regarding the use of psychoactive substances by adolescents are also alarming and call attention to the earliness at which its usage happens. In Brazil, the average age for the first contact with alcohol and tobacco is 12.5 years, 13.9 years for marijuana and 14.4 years for cocaine (Galduróz, Noto, Fonseca, \& Carlini, 2004). In addition to increasing the risk of lifelong overconsumption, experimentation of psychoactive substances during adolescence is identified as an exposure factor to health problems during adolescence itself and also during adulthood (Acosta, Fernández, \& Pillon, 2011).

There are a lot of negative outcomes related to the use of psychoactive substances. Aside from the specific physiological effects, studies indicate that there are greater risk for involvement in accidents and brawls, more difficulties in academic and professional performance, elevated incidence of having sex with a greater number of partners and without condom, more problems regarding depression, anxiety, and low self-esteem, as well psychiatric and behavioral disorders in individuals who use and abuse of psychoactive substances compared with those that do not use this kind of substances (Collins Fantasia et al., 2012; Cruzeiro et al., 2008; Horta, Horta, \& Horta, 2012).

As for risk factors concerning the use of psychoactive substances, there's evidence that older male teenagers, with a greater school lag and belonging to the upper class and the upper middle class; as well as adolescents who have paid work and family conflicts, show the highest prevalences of drug use in life (Acosta et al., 2011; Galduróz et al., 2004; Noal, Menezes, Araújo, \& Hallal, 2010). According to Tavares, Beria and Lima (2001), stressful factors that may traumatize the teen, such as being victim of abuse and assault, are also associated with a risk increase of drug use. On the other hand, harmonious family relationships, good school performance, participation in social groups and religious habits are singled out as protective factors in relation to the experimentation or use of substances (Schenker \& Minayo, 2005).

Themes such as violence and drugs use are highly relevant among students in Brazil. Among Brazilian schoolchildren, the prevalence of alcohol usage in the last year was $42.2 \%, 9.6 \%$ for tobacco, $3.7 \%$ for marijuana and $1,8 \%$ for cocaine. Lifetime use of alcohol was estimated at $60.5 \%, 21.1 \%$ for use in the month, $2.7 \%$ for frequent use and $1.6 \%$ for heavy use (large amounts per episode of consumption). Heavy beverage was more prevalent in public schools than in private schools (Galduróz et al., 2010). Also, data from the Pesquisa Nacional de Saúde do Escolar (PENSE 2012) [Lifetime use of illicit drugs and associated factors among Brazilian schoolchildren, National Adolescent School-based Health Survey, PeNSE 2012] show that 7.3\% of prevalence of lifetime use of illicit drugs and this behavior was associated to the experience of some type of aggressive behavior [OR - 1.28 (95\%: 1.17 to 1.41) $\mathrm{p}<0.001$ ] (Horta et al., 2014). Beyond that, data from schools in Brazil come from state capitals or cities larger than 100,000 inhabitants and this paper aimed to access these phenomena among students from medium cities (70,000 inhabitants). 
In the present study, it was intended to examine the exposure to violence phenomena and psychoactive substance use among teenager students in Brazil. It has been sought to understand the prevalences of these phenomena and in addition to investigate its association, considering potential confounding factors. It was expected an association between violence exposure and substance use, even controlling for confounding variables. Moreover, the current investigation aimed also to gather information about the phenomena in small cities where scarce research has been conducted so far.

\section{METHOD}

\section{Sample}

All the schools in the municipalities of Lajeado and Sapiranga, both mediumsized in the countryside of the Rio Grande do Sul state were visited in 2012. The sample was composed by 3,547 students, 1,623 (45.8\%) being male and 1,924 $(54.2 \%)$ female, aged between 12 and 17 years $(M=14 ; S D=1.66)$.

\section{Measures}

A questionnaire with 158 questions, based on the model of the measures used in major national studies (Carlini et al., 2007; Carlini et al., 2010) was developed by the research team, having been standardized and pre-tested. In this study, the outcomes examined were: use of tobacco, alcohol and illicit drugs (cocaine, crack, marijuana, ecstasy and inhalants) in the last year. The exposure of interest was to witness a violence situation in life. All these variables were of the dichotomous type, obtained with YES or NO answers. In the adjusted analysis, the variables gender; use of alcohol or tobacco by parents; psychic morbidity measured through the Self Reporting Questionnaire (SRQ-20) -were included. In a second moment, use of other substances (cocaine, crack, marijuana, ecstasy and inhalants) was also included in the adjusted analysis.

\section{Procedures}

In order to achieve this school-based cross-sectional study a random sampling was performed per class, preserving the sample's proportionality by gender, age, municipality and education network (municipal public, state public, and private $\left.^{1}\right)$. All classes were related as entrants to a drawing. In all, 214 classes were visited in schools of Lajeado and 75 classes in schools of Sapiranga. Both municipalities presented a quite distinct concentration of students per classes, however, Lajeado was the city with the largest number of school enrollments because it plays a more evident role of micro-regional pole, in different aspects, among them, schooling. People with cognitive or physical disabilities who were, for that reason, unable to answer the questionnaire, had no help or special atten- 
tion. Each one received a questionnaire, did not answer it and, later, the unfilled questionnaires were excluded. Thereby, these students were also not identified by the colleagues.

After the agreement of both departments of education and school's managers, representatives from each school reported to the students' guardians information about the study's objectives, data collection procedures and ethical aspects. Emphasis was given to the information that the questionnaire would be filled by the participants and would preserve the anonymity of those who answer it. The informed consent forms were distributed and collected by schools prior to data collection, and students without a guardian's permission to participate or those who did not wished to respond, were instructed to receive the questionnaire and return it in blank, thus avoiding the identification of nonrespondents in the classroom.

The implementation of the questionnaire took place in classroom and all the data collection lasted six weeks. After the survey, all questionnaires were collected in urns prepared specially for the study, sealed soon after the visit of each class and opened later, only in the room reserved for processing and data typing.

For quality assurance, data collection was accompanied in-person by specially trained field supervisors and all visits to classes were checked with the schools. The instruments were typed into the Epidata 3.5 software with double entry, for checking and correction of possible typos. A first round of descriptive analysis allowed the identification and correction of any inconsistencies. In all, were computed, among refusals and deletions by inconsistencies, losses of approximately $9.4 \%$ of the interviews. The study had approval of the Research Ethics Committee of Unisinos University through protocols 074/2011 and $028 / 2012$, authorization of the schools' principals and consent of students' guardians who signed the informed consent term (ICT).

\section{Data Analysis}

A descriptive and gross analysis was performed and adjusted by Poisson regression, preceded by control to effect of variable design school. Data analysis was conducted using the Stata 11.0 program. To estimate the Prevalence Ratio (PR) both gross and adjusted, in addition to their confidence intervals of $95 \%$ (CI 95\%) and $p$-value, Poisson regression was used. The analyses were controlled for design effect for the school variable. The outcomes used in alcohol and tobacco in the year showed average estimates of effect of delineation for the school variable equal to 0.326 and 0.059 , respectively, justifying the control of such effect in the subsequent analyses. In the current study, the exposure of interest was to witness a violence situation in life and "use of tobacco", "use of alcohol" and "illicit drugs in the last year" were the outcomes examined. As already mentioned all these variables were dichotomous, obtained with YES or NO answers. In the adjusted analysis, the variables gender, use of alcohol or tobacco by parents and 
psychic morbidity were included. After, the previous variables plus the use of substances from other groups were included (e.g., when alcohol was used as an outcome, the use of any of the other substances under study was also monitored). Associations at a 95\% confidence level, with $p$ values $\leq .05$, and with statistical power of $80 \%$ or higher were considered statistically significant.

\section{RESULTS}

The prevalence of tobacco use in the year was 9.8\% (CI95\%: 8.8\%-10.8\%); of alcohol in the year amounted to $46.1 \%$ (CI95\%: 44.6\%-47.7\%) and of illicit drugs in the year was $10.9 \%(C I 95 \%: 9.9 \%-12.0 \%)$. Just over one-third of the sample $(35.7 \%$; C195\%: 34.2\%-37.3\%) claimed to have witnessed violence situation in life (Table 1).

Table 1. Prevalences and Respective Confidence Interval of Alcohol, Tobacco and Illicit Drugs Use and Exposure to Situations of Violence

\begin{tabular}{lcc}
\multicolumn{1}{c}{ Variable } & Prevalence & CI95\% \\
\hline Use of tobacco in the year & $9.8 \%$ & $8.8 \%-10.8 \%$ \\
Use of alcohol in the year & $46.1 \%$ & $44.6 \%-47.7 \%$ \\
Use of illicit drugs in the year & $10.9 \%$ & $9.9 \%-12.0 \%$ \\
Exposure to situations of violence & $35.7 \%$ & $34.2 \%-37.3 \%$ \\
\hline
\end{tabular}

Note. Analysis preceded by control with the purpose of design by the school variable

Gross analysis indicated statistically significant association $(p<.001)$ between exposure to violence in life and use of tobacco, alcohol and illicit drugs in the last year (Table 2).

Table 2. Prevalence Ratio (PR) and Respective Confidence Intervals for the Use of Substances According to Exposure to Violence, Estimated in Gross Analysis by Poisson Regression

\begin{tabular}{lcccc} 
& Use in the year & \multicolumn{3}{c}{ Gross Analysis } \\
\cline { 2 - 4 } & & $P R$ & $C 195 \%$ & $p$ value \\
\hline Tobacco & 2.81 & $2.29-3.46$ & $<.001$ \\
Alcohol & 1.61 & $1.51-1.73$ & $<.001$ \\
Illicit drugs & 1.87 & $1.55-2.25$ & $<.001$ \\
\hline
\end{tabular}

Note. Analysis preceded by control with the purpose of design by the school variable

When the analysis was adjusted for the variables of gender, use of alcohol or tobacco by parents and psychic morbidity (SRQ20), exposure to situations of violence in life proved to be strongly associated to all drugs analyzed (Table 3). The probability of tobacco use in the year was 2.49 times greater (CI95\%: $1.92-$ 
$3.25 ; p<.001)$ among students who witnessed violence than among those who haven't; 49\% higher for use of alcohol (CI95\%: $1.35-1.59 ; p<.001)$ and $60 \%$ higher for illicit drug use (CI95\%: 1.27-2.01; $p<.001)$.

Table 3. Prevalence Ratio (PR) and Respective Confidence Intervals for the Use of Substances According to Exposure to Violence, Estimated in Adjusted Analysis by Poisson Regression

\begin{tabular}{lccc}
\multirow{2}{*}{ Use in the year } & \multicolumn{3}{l}{$\begin{array}{l}\text { Adjusted by gender, use of alcohol or tobacco by parents } \\
\text { and morbidity (SRQ20) }\end{array}$} \\
\cline { 2 - 4 } & $P R$ & $C 195 \%$ & $p$ value \\
\hline Tobacco & 2.49 & $1.92-3.25$ & $<.001$ \\
Alcohol & 1.46 & $1.35-1.59$ & $<.001$ \\
Illicit drugs & 1.60 & $1.27-2.01$ & $<.001$ \\
\hline
\end{tabular}

Note. Analysis preceded by control with the purpose of design by the school variable

However, when the use of other substances (cocaine, crack, marijuana, ecstasy and inhalants) variable was added to the adjusted analysis, this association remained only for tobacco use in the year $(P R=1.67 ; C I 95 \%: 1.32-2.12 ; p<.001)$ and use of alcohol in the year $(P R=1.35 ; C I 95 \%: 1.24-1.47 ; p<.001)$. In this case, no difference was observed between having been exposed to situations of violence or not for the use of illicit drugs in the year $(P R=1.08$; $C 195 \%$ : 0.87-1.35; $p=.466$ ) (Table 4).

Table 4. Prevalence Ratio (PR) and Respective Confidence Intervals for the Use of Substances According to Exposure to Violence, Estimated in Adjusted Analysis Also to the Use of Other Substances, by Poisson Regression

\begin{tabular}{|c|c|c|c|}
\hline \multirow[t]{2}{*}{ Use in the year } & \multicolumn{3}{|c|}{$\begin{array}{l}\text { Adjusted by gender, use of alcohol or } \\
\text { tobacco by parents and morbidity } \\
(\text { SRQ20) + use of substances of other } \\
\text { group in the year }\end{array}$} \\
\hline & $P R$ & СI95\% & $p$ value \\
\hline Tobacco & 1.67 & $1.32-2.12$ & $<.001$ \\
\hline Alcohol & 1.35 & $1.24-1.47$ & $<.001$ \\
\hline Illicit drugs & 1.08 & $0.87-1.35$ & .466 \\
\hline
\end{tabular}

DISCUSSION

It has been observed expressive prevalences of alcohol, tobacco and illicit drugs use, as well as reference to exposure to violence situations. These evidences are worrisome and are followed by the concern with these phenomena in the field of public health in Brazil as a whole (Brasil, 2010). Alcohol, the most 
commonly drug reported by the participants, have their consumption in life referenced by more than half of Brazilian adolescents (Carlini et al., 2010; Malta et al., 2011). Among the 7,939 teenagers interviewed in the II Household Survey on psychotropic drugs in Brazil - 2005, 22.8\% reported having already made use of drugs in their lives. Adolescence is singled out as the development stage in which the use of psychoactive substances begin. Between the ages of 12 and 17 years, is already possible to notice the use of various substances by youngsters, such as alcohol, whose consumption was referred by $54.3 \%$ of teens; tobacco, referred by $15.2 \%$ of them; and marijuana, referred by $4.1 \%$ of the teenagers interviewed in the national study (Carlini et al., 2007).

In this study, exposure to violence and use of licit and illicit drugs showed association. With the purpose of adjusting the estimations of prevalence ratio, three variables were chosen: a demographic one - the gender of the students interviewed; a variable related to the domestic environment - the use of tobacco and alcohol by the respondents' parents; and lastly, a score compatible with psychiatric morbidity according to the interviewees' answers, given that these variables or dimensions represented by them tend to be associated with both the exposure of interest as with the assumed outcomes. This association was confirmed in the preliminary analyses of this study. Exposure to violence remained associated with the use of each of the studied substances (tobacco, alcohol, and illicit drugs).

Although the exposure of interest in this study has been to witness a situation of violence in life, data here presented support Hanewinkel, Isensee, Maruska, Sargent and Morgenstern's (2010) study which showed that aggressors make more use of cigarettes than no aggressors. Other studies also point out that violence protagonists tend to use alcohol (Hemphill et al., 2011; King, Horwitz, Berona, \& Jiang, 2013; Klomek et al., 2011), marijuana (Hemphill et al., 2011; Klomek et al., 2011), and other substances frequently (King et al., 2013; Klomek et al., 2011).

Findings concerning the relationship between violence and use of substances are not homogeneous, possibly due to differences as to how the evidence is collected and the construction of the variables under consideration. Garcia-Continente, Giménez and Adell (2010) found a negative association between the experimental use of marijuana for boys and the regular use of alcohol for school girls in Barcelona and having been a victim of violence in the school environment.

In the same line of thought, McMahon, Reulbach, Keeley, Perry and Arensman (2010), realized that young people who referred having four or more episodes of drunkenness in the year preceding the survey didn't suffered victimization, and these authors found no association between the use of tobacco and other drugs and exposure to violence. Still, when it comes to students from the north of England, the study of Rivers, Poteat, Noret and Ashurst (2009) attested that having been a victim of violence was not a predictor of substance use. The differences between results of the present study and the afore mentioned researches aside from stressing the importance and aspect of data discovery, also suggest 
the influence of cultural issues in Brazil that may have influenced the association between these processes. Unfortunately, nowadays in Brazil, there are evidences that violence is increasing significantly. Serious aggressive episodes are observed in schools, in communities and also in families. Brazilians report feelings of insecurity and fear with important frequency as well as relationships based on aggression and non-respectful attitudes are also observed. Individualism is also a cultural value and characteristic of Brazilian context that may account for the increasing of violence and, as a consequence or an associated factor, the increasing use of drugs. (Brasil, 2010; Dahlberg \& Krug, 2007; Fuchs, 2008; Veloso, Magalhães, Dell'Aglio, Cabral, \& Gomes, 2013)

Similarly, victimization by bullying, a specific form of violence among peers, appears often associated with substance use. The study of Luk, Wang and Simons-Morton (2010) revealed a positive association between suffering bullying and substance use, however, this association remained only for boys after the control of the depression variable. Positive association between suffering bullying and use of alcohol was also found in McGee, Valentine, Schulte and Brown's (2011) research. Similarly, it has been identified among students from Peru (Romaní \& Gutiérrez, 2010) and adolescents residing in the South of Brazil (Silva et al., 2012) positive association between use of licit and illicit substances and victimization. Suffering bullying is also positively associated with the use of marijuana among students from Zambia (Siziya et al., 2013) and with cigarette and alcohol use among Italian pupils (Vieno, Gini, \& Santinello, 2011).

Such findings call attention to the fact that the involvement in violence situations can be associated with the use of substances and that these phenomena represent important risks for the development of teenagers. The involvement in situations of violence is associated with a wide range of potential losses, as previously mentioned in the introduction (Cruzeiro et al., 2008; Radliff et al., 2012). Likewise, this is detected on the use of psychoactive substances (Cruzeiro et al., 2008; Horta et al., 2012).

As a limitation, it is necessary to point out that the study design is cross sectional, which does not allow establishing relations of cause and effect among these phenomena. In this sense, future studies, preferably with a longitudinal design, should be conducted. It is noted that international studies have made use of longitudinal designs in order to investigate the relationship among these processes (Hanewinkel et al., 2010; Hemphill et al., 2011; King et al., 2013; Klomek et al., 2011; Low \& Espelage, 2013).

Adolescence is a stage of increasing autonomy in relation to parental figures It is a developmental task of teens to shun themselves from parents in order to build their identities, turning to their peer group. In this dynamic, situations of violence may occur as well as peer pressure for drug consumption (Acosta et al., 2011; Hong \& Espelage, 2012; Vieira, Aerts, Freddo, Bittencourt, \& Monteiro, 2008). Therefore, it is necessary to include in future investigations other variables connected to family or to friendship relationships and popularity in a peer group (Lee, 2012). 
Based on the findings, there was an overlap of risk factors regarding the use of substances and exposure to violence. Studies show, however, some contradictory results that may suggest cultural specificities that deserve close attention. This way, it takes a comprehensive and integrated effort with various sectors of society so that preventive and interventional actions succeed. Public policies for health and safety of children and adolescents should integrate into the school, family and other collective spaces, aside from also sharing a dynamic vision of protection and risk factors of this important stage of the life cycle.

\section{ACKNOWLEDGEMENTS}

CAPES foundation for doctoral fellowship in the country (Cristina Lessa Horta), abroad (Guilherme Welter Wendt) and productivity grant (Carolina Saraiva de Macedo Lisboa), and FAPERGS foundation for the doctoral $\mathrm{PhD}$ scholarship in the country (Vanessa Andina Teixeira). CNPq foundation for research funding (Universal Grant / 2013) .

\section{REFERENCES}

Acosta, L. D., Fernández, A. R., \& Pillon, S. C. (2011). Factores sociales para el uso de alcohol en adolescentes y jóvens. Revista Latino-Americana de Enfermagem, 19, 771-781.

Brasil. (2010). Diretrizes nacionais para a atenção integral à saúde de adolescentes e jovens na promoção, proteção e recuperação da saúde. Ministério da Saúde, Secretaria de Atenção em Saúde, Departamento de Ações Programáticas Estratégicas. Brasília: Ministério da Saúde.

Carlini, E. A.; Galduróz, J. C.; Noto, A. R.; Carlini, C. M.; Oliveira, L. G.; Nappo, S. A.; Moura, Y. G.; Sanchez, Z. V. D. M. (2007). II Levantamento domiciliar sobre o uso de drogas psicotrópicas no Brasil: estudo envolvendo as 108 maiores cidades do país - 2005. São Paulo: São Paulo: CEBRID - Centro Brasileiro de Informações sobre Drogas Psicotrópicas/UNIFESP - Universidade Federal de São Paulo.

Carlini, E. A., Noto, A. R., Sanchez, Z. M., Carlini, C. M. A., Locatelli, D. P., Abeid, L. R.,...Moura, Y. G. (2010). VI Levantamento Nacional sobre o Consumo de Drogas Psicotrópicas entre Estudantes do Ensino Fundamental e Médio das Redes Pública e Privada de Ensino nas 27 Capitais Brasileiras 2010. São Paulo: CEBRID - Centro Brasileiro de Informações sobre Drogas Psicotrópicas/UNIFESP - Universidade Federal de São Paulo.

Collins Fantasia, H., Sutherland, M. A., \& Kelly-Weeder, S. (2012). Gender differences in risky sexual behavior among urban adolescents exposed to violence: Gender differences in risky sexual behavior. Journal of the American Academy of Nurse Practitioners, 24(7), 436-442. doi:10.1111/j.17457599.2012.00702.x

Cruzeiro, A. L. S., Silva, R. A., Horta, B. L., Souza, L. D. M., Faria, A. D., 
Pinheiro, R. T.,...Ferreira, C. D. (2008). Prevalência e fatores associados ao transtorno da conduta entre adolescentes: um estudo de base populacional. Cadernos de Saúde Pública, 24(9), 2013-2020. doi:10.1590/S0102311X2008000900007

Dahlberg, L. L., \& Krug, E. G. (2006). Violência: um problema global de saúde pública. Ciência \& Saúde Coletiva, 11, 1163-1178. doi:10.1590/S141381232006000500007.

Fuchs, M. (2008). Impact of school context on violence at schools: a multi-level analysis. International Journal on Violence and Schools, 7(1), 20-42.

Galduróz, J. C. F., Noto, A. R., Fonseca, A. M., \& Carlini, E. A. (2004). V Levantamento Nacional Sobre o Consumo de Drogas Psicotrópicas entre Estudantes do Ensino Fundamental e Médio da Rede Pública de Ensino nas 27 Capitais Brasileiras. São Paulo: CEBRID- Centro Brasileiro de Informações sobre drogas psicotrópicas/ UNIFESP- Universidade Federal de São Paulo.

Garcia-Continente, X., Pérez-Giménez, A., \& Adell, M. N. (2010). Factores relacionados com el acoso escolar (bullying) em los adolescentes de Barcelona. Gaceta Sanitaria, 24(2), 103-108. doi:10.1016/j.gaceta.2009.09.017

Hanewinkel, R., Isensee, B., Maruska, K., Sargent, J. D., \& Morgenstern, M. (2010). Denormalising smoking in the classroom: does it cause bullying? Journal of Epidemiology and Community Health, 64(3), 202-208. doi:10.1136/jech.2009.089185

Hemphill, S. A., Kotevski, A., Herrenkohl, T. I., Bond, L., Kim, M. J., Toumbourou, J. W., \& Catalano, R. F. (2011). Longitudinal consequences of adolescent bullying perpetration and victimization: a study of students in Victoria, Australia. Clinical Behaviour and Mental Health, 21(2), 107-116. doi: $10.1002 / \mathrm{cbm} .802$

Hong, J. S., \& Espelage, D. L. (2012). A review of research on bullying and peer victimization in school: an ecological system analysis. Agression and Violent Behavior, 17, 311-322. doi:10.1016/j.avb.2012.03.003

Horta, R. L., Horta, B. L., \& Horta, C. L. (2012). Uso de drogas e sofrimento psíquico numa instituição universitária do Sul do Brasil. Psicologia em Revista (Online), 18(2), 264-276. doi:10.5752/P.1678-9563.2012v18n2p264

Horta, R. L., Horta, B. L., Costa, A. W. N., Prado, R. R., Oliveira-Campos, M., Malta, D. C. (2014). Uso na vida de substâncias ilícitas e fatores associados entre escolares brasileiros, Pesquisa Nacional de Saúde do Escolar (PeNSE 2012).0Revista Brasileira de Epidemiologia, 17(1), 31-45. doi: 10.1590/1809-4503201400050004

King, C. A., Horwitz, A., Berona, J., \& Jiang, Q. (2013). Acutely suicidal adolescents who engage in bullying behavior: 1-year trajectories. Journal of Adolescent Health, 53(1), S43-S50. doi:10.1016/j.jadohealth.2012.09.016

Klomek, A. B., Kleinman, M., Altschuler, E., Marrocco, F., Amakawa, L., \& Gould, M. S. (2011). High school bullying as a risk for later depression and suicidality. Suicide and Life-Threatening Behavior, 41(5), 501-515.

Lee, R. (2012). Community violence exposure and adolescent substance use: 
does monitoring and positive parenting moderate risk in urban communities? Community Violence Exposure and Substance Use. Journal of Community Psychology, 40(4), 406-421. doi:10.1002/jcop.20520

Low, S., \& Espelage, D. (2013). Differentiating cyber bullying perpetration from non-physical bullying: commonalities across race, individual, and family predictors. Psychology of Violence, 3(1), 39-52. doi:10.1037/a0030308

Luk, J. W., Wang, J., \& Simons-Morton, B. G. (2010). Bullying victimization and substance use among U. S. adolescents: mediation by depression. Prevention Science, 11(4), 355-359. doi:10.1007/s11121-010-0179-0

Luk, J. W., Wang, J., \& Simons-Morton, B. G. (2012). The co-occurrence of substance use and bullying behaviors among U.S. adolescents: understanding demographic characteristics and social influences. Journal of Adolescence, 35, 1351-1360. doi:10.1016/j.adolescence.2012.05.003

Madruga, C. S., Laranjeira, R., Caetano, R., Ribeiro, W., Zaleski, M., Pinsky, I., \& Ferri, C. P. (2011). Early life exposure to violence and substance misuse in adulthood-The first Brazilian national survey. Addictive Behaviors, 36(3), 251-255. doi:10.1016/j.addbeh.2010.10.011

Malta, D. C., Mascarenhas, M. D. M., Porto, D. L., Duarte, E. A., Sardinha, L. M., Barreto, S. M., \& Neto, O. L. M. (2011). Prevalência do consumo de álcool e drogas entre adolescentes: análise dos dados da Pesquisa Nacional de Saúde Escolar. Revista Brasileira de Epidemiologia, 14(supl. 1), 136-146. doi:10.1590/S1415-790X2011000500014

McGee, E., Valentine, C., Schulte, M. T., \& Brown, S. A. (2011). Peer victimization and alcohol involvement among adolescents self-selecting into a schoolbased alcohol intervention. Journal of Child \& Adolescent Substance Abuse, 20(3), 253-269. doi:10.1080/1067828X.2011.581904

McMahon, E. M., Reulbach, U., Keeley, H., Perry, I. J., \& Arensman, E. (2010). Bullying victimisation, self harm and associated factors in Irish adolescent boys. Social science \& medicine, 71, 1300-1307. doi:10.1016/j.socscimed.2010.06.034

Noal, R. B., Menezes, A. M. B., Araújo, C. L., \& Hallal, P. C. (2010). Experimental use of alcohol in early adolescence: the 11-year follow-up of the 1993 Pelotas (Brazil) birth cohort study. Cadernos de Saúde Pública, 26(10), 1937-1944. doi:10.1590/S0102-311X2010001000010

Ok, S., \& Aslan, S. (2010). The school bullying and perceived parental style in adolescents. Procedia - Social and Behavioral Sciences, 5, 536-540. doi:10.1016/j.sbspro.2010.07.138

Radliff, K. M., Wheaton, J. E., Robinson, K., \& Morris, J. (2012). Illuminating the relationship between bullying and substance use among middle and high school youth. Addictive Behaviors, 37, 569-572. doi:10.1016/j. addbeh.2012.01.001

Rivers, I., Poteat, V. P., Noret, N., \& Ashurst, N. (2009). Observing bullying at school: the mental health implications of witness status. School Psychology Quarterly, 24(4), 211-223. doi:10.1037/a0018164 
Romaní, F., \& Gutiérrez, C. (2010). Auto-reporte de victimización escolar y factores associados em escolares peruanos de educación secundaria, año 2007. Revista Peruana de Epidemiología, 14(3), 1-9.

Schenker, M., \& Minayo, M. C. S. (2005). Fatores de risco e de proteção para o uso de drogas na adolescência. Ciência e Saúde Coletiva, 10(3), 707-717. doi: $10.1590 /$ S1413-81232005000300027.

Silva, R. A., Cardoso, T. A., Jansen, K., Souza, L. D. M., Godoy, R., V., Cruzeiro, A. L. S.,... Pinheiro, R. T. (2012). Bullying and associated factors in adolescents aged 11 to 15 years. Trends in Psychiatry and Psychotherapy, 34(1), 19-24. doi:10.1590/S2237-60892012000100005

Siziya, S., Muula, A. S., Besa, C., Babaniyi, O., Songolo, P., Kankiza, N., \& Rudatsikira, E. (2013). Cannabis use and its socio-demographic correlates among in-school adolescents in Zambia. Italian Journal of Pediatrics, 39, $1-5$.

Tavares, B. F., Beria, J. U., \& Lima, M. S. (2001). Prevalência do uso de drogas e desempenho escolar entre adolescentes. Revista de Saúde Pública, 35(2), 150-158. doi:10.1590/S0034-89102001000200008

Tortorelli, M. F. P., Carreiro, L. R. R., \& Araújo, M. V. (2010). Correlações entre a percepção da violência familiar e o relato de violência na escola entre alunos da cidade de São Paulo. Psicologia : Teoria e Prática, 12(1), 32-42.

Veloso, M. M. X., Magalhães, C. M. C., Dell'Aglio, D. D., Cabral, I. R., \& Gomes, M. M. (2013). Notificação da violência como estratégia de vigilância em saúde: perfil de uma metrópole do Brasil. Ciência \& Saúde Coletiva, 18(5), 1263-1272.

Vieira, P. C., Aerts, D. R. G. C., Freddo, S. L., Bittencourt, A., \& Monteiro, L. (2008). Uso de álcool, tabaco e outras drogas por adolescentes escolares em município do Sul do Brasil. Cadernos de Saúde Pública, 24(11), 2487-2498. doi:10.1590/S0102-311X2008001100004

Vieno, A., Gini, G., \& Santinello, M. (2011). Different forms of bullying and their association to smoking and drinking behavior in Italian adolescents. Journal of School Health, 81(7), 393-399.

World Health Organization Global consultation on violence and health. (1996). Violence: a public health priority. Geneva: WHO. 